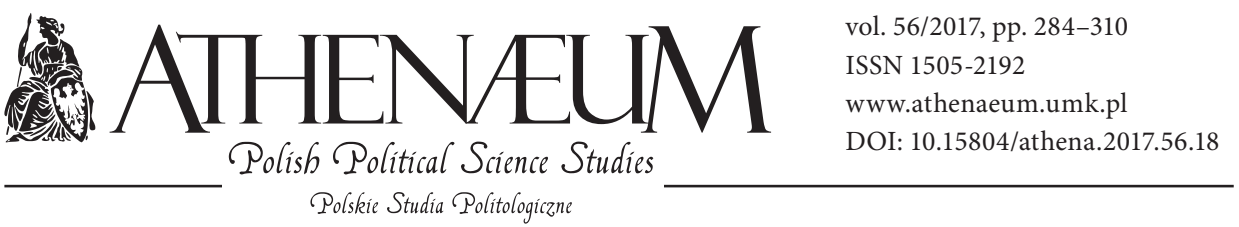

\author{
INTERCULTURALISM \\ IN CRISIS RESPONSE OPERATIONS
}

\author{
MIĘDZYKULTUROWOŚĆ W OPERACJACH REAGOWANIA \\ KRYZYSOWEGO
}

Magdalena El Ghamari*

\begin{abstract}
Deriving from the very concept, colere (culture) should indicate a significant, and at the same time, the main factor which is a human society. Culture exists in close proximity to people and their activities. Subsequently, through participation in a particular social group, everyone may create a system which is called culture. The foregoing interaction highlights the impact of culture on human behaviour and the people's ability to model and create "the foundations of culture". Culture forms the human individuality, which over time improves and enriches it, or on the contrary - affects its gradual loss. This means that man exists due to culture - and culture positively coexists or negatively disappears through human actions.

Dynamic trends in the civilizational development of countries, changes in the environment, progress in science, engineering and technology, and in particular information lead to the appearing of
\end{abstract}

Pod pojęciem colere (kultury) należy wskazywać znaczący i jednocześnie główny czynnik je konstytuujący, jakim jest ludzka społeczność. Kultura istnieje $\mathrm{w}$ ścisłym powiązaniu $\mathrm{z}$ człowiekiem i jego działalnością. Zaś każdy z nas poprzez przynależność do określonych grup społecznych może kreować system, jakim jest kultura. Zachodząca interakcja podkreśla wpływ kultury na postępowanie człowieka oraz na ludzką umiejętność modelowania i tworzenia „podstaw kulturowych". Kultura kształtuje ludzkie indywidualności, które z czasem ją wzbogacają i udoskonalają, bądź też odwrotnie - wpływają na jej stopniowe zatracanie. Oznacza to, że człowiek istnieje dzięki kulturze i kultura - pozytywnie - istnieje bądź - negatywnie - zanika poprzez ludzkie działania.

Dynamiczne trendy w rozwoju cywilizacyjnym państw, zmiany $\mathrm{w}$ środowisku naturalnym, postęp w nauce, technice i technologii, głównie informacyjnej, sprawiają, że pojawianie się

* Collegium Civitas, Laboratory Centre for Research on Social and Economic Risks. 
new socio-cultural tools for new policy scenarios of military security.

The constant dynamism of these phenomena requires, from our currently formed Armed Forces, mainly bearing the burden of maintaining military security, but also new, unconventional and at the same time resolute response, even to minor regional conflicts which incidentally may become dangerous for Poland over time. Responding to emerging threats will not be unilateral or brief, as the experiences in the former Yugoslavia and in the Middle East indicate.

For a long time, the security of the states was based on military force. Force and sovereignty were the cornerstones of the system of national states. The rest of the military structure was subordinated to the remaining components of the state, e.g., natural resources, geographic location, demographic potential, scientific and technological advancement, etc. Over time, this condition has changed. After the Second World War, two alliances of states centered around the empires of powerful military forces were formed. The rise of military potentials on both sides did not cause the necessity to their use. These potentials have become a great means of deterrence and political influence on their opponents.

Keywords: interculturalism, crisis response operations, culture, military nowych scenariuszy polityki bezpieczeństwa militarnego musi nieść ze sobą nowe narzędzia społeczno-kulturowe.

Ciągła dynamika tych zjawisk wymaga od naszych obecnie tworzonych Sił Zbrojnych, głównego podmiotu dźwigającego ciężar utrzymania bezpieczeństwa militarnego kraju, nowego i niekonwencjonalnego, lecz zdecydowanego reagowania nawet na niewielkie konflikty regionalne, które z czasem mogą stać się niebezpieczne dla Polski. Reagowanie na pojawiające się zagrożenia nie będzie aktem jednostronnym i krótkotrwałym, jak wskazują doświadczenia w byłej Jugosławii i na Bliskim Wschodzie.

Przez długi czas bezpieczeństwo państw oparte było na sile militarnej. Siła i suwerenność stanowiły kamienie węgielne systemu państw narodowych. Budowie siły wojskowej podporządkowane zostały inne komponenty stanowiące o pozycji państwa: zasoby naturalne, położenie geograficzne, potencjał demograficzny, stan zaawansowania naukowego i technologicznego itp. Z czasem stan ten uległ zmianie. Po drugiej wojnie światowej powstały dwa bloki państw skupione wokół mocarstw dysponujących potężną siłą wojskową. Narastanie potencjałów militarnych po obu stronach nie powodowało konieczności ich użycia. Potencjały te stały się doskonałym środkiem odstraszania i politycznego oddziaływania na swoich przeciwników.

Słowa kluczowe: międzykulturowość, operacje reagowania kryzysowego, kultura, wojskowość

\section{INTRODUCTION: SITUATING THE PROBLEM}

One of the important elements in the international order, which was at the turn of the last several years, is the increasing role of the activities undertaken by international organizations and national bodies in forming the global order. Along with changes in the international environment and an increase in the activity of the stabilization of Western countries, their armed forces more often are obliged to face the threats resulting from the culture, customs, traditions, religion or 
language of the different operating environment. Intercultural policy for years has been the subject of pride in many European countries. But in recent years it has become a problem that European governments are not able to manage.

In Europe, it has already been made clear that it is time to revise inter-cultural policy, which appears as the famous "multiculti" - a source of the European sense of pride for so many years. The challenge of interculturality in crisis response operations is first to identify, and second to provide, a safe working environment. These actions are necessary to obtain, by coalition forces, information, the possibility of sharing it along with understanding of the situation, synchronization of activities and assessment of progress in the agreement with partners of international organizations and indigenous peoples.

Based on the international experience, it can be concluded that inter-cultural upskilling is an extremely important and legitimate element of the armed forces training course. Moreover, in the perspective of future operations, it is relevant to conduct incisive research of its diverse operating environment.

It is, therefore, appropriate to rely on all possible experiences in this field and to analyse the operations undertaken by the civil and military components. On the other hand, it can be argued that the formation of an international coalition requires not only political decisions but also a respect, trust, patience, a high level of allies knowledge and a cultural sensitivity. In order to be more effective and prevent emerging problems, civil and military organizations should undertake a number of initiatives related to the implementation of cultural awareness. Culture and aspects of interculturality should be systematically included in training, doctrines and planning procedures for operations held outside the country. Cultural experts should be involved in the operation from the beginning so that they can support their participants (Kucharczyk, 1996, p. 51-71).

It should be emphasized that cultural awareness must not only be included in the planning process, but also throughout the whole operation period. Determinants and cultural factors should be prepared and collected to create a common information base of a given conflict region. Due to the emphasis on the understanding of the civilian population, its customs and tradition, the skill of information acquisition through the human factor is of particular importance. The essence of this component is to acquire information. However, in the context of action, attention should be paid to the quality and sources of this information, which are the basis of an unconventional acting in the area of operation. It is necessary to highlight the changing action conditions in which basic cultural information may occur not to be sufficient (Best, Cumming, 2007, p. 4-8). 


\section{RESEARCH METHODOLOGICAL BASES}

It is worth highlighting that interculturality is an interdisciplinary area of knowledge. It is therefore justified to argue that, despite numerous studies and experiments in this field, interculturality and intercultural awareness are a challenge for the armed forces as well as for those who provide training in the environment of conducting the operations. Through the systematic approach to the problem of the cultural environment, to the specificity of planning and to the operational capacity, it is necessary to identify knowledge along with understanding and ability to communicate in a foreign situation. The analysis of this general issue will also consider more specific research problems, such as the foundation of modern emergency response operations, the impact of the cultural environment, achieving the purpose of the operation, and also the problem of preparing the operation participants to achieve objectives in terms of interculturalism.

Adaptation of the research problem of multiculturalism in military operations seems to be expedient also due to the lack of Polish scientific literature discussing intercultural issues in terms of achieving the objectives of emergency response operations held by the Armed Forces of the Republic of Poland.

Literature related to the interculturalism and its correlation with the activities of the Armed Forces consists mainly of foreign publications and literature associated with crisis response operations based primarily on research activities, monographs and other academic studies produced in the area of security and international relations.

Accordingly to the foregoing assumption, the purpose of this article is to identify cognitive interculturalism and its role in crisis response operations. While the utilitarian purpose is to determine changes in objectives of a training program designed for participants in emergency response operations in the field of intercultural communication.

The object of the conducted research was to implement environmental emergency response operations and to subject the characteristics of the environment and participants in the multinational forces.

The contribution of International Security Assistance Force in crisis response, despite the results of the politico-military situation and the changing significance of armed violence in achieving political conflict in Europe and the world, continues to play a significant role. The essence of the modification also affects the changes taking place in the armed forces and determines the environmental operations. 
Conclusions from the analysis of contemporary actions indicate that the risk of operations in the area is often associated with a lack of understanding or lack of participants' knowledge of cultural backgrounds and social conflict. Therefore, interculturalism is becoming an important part of our lives not only in terms of crisis response operations but also the functioning of an open European society.

The main reason to undertake this study was to identify the problems arising from the perception and the definition of the unknown culture and the problems of security and defence in the field of interculturalism. Social sciences recognize the subject of the study as a real and in the same time abstract.

A real subject defines everything that is able to observe with the senses. By analyzing this approach one can conclude that the senses record, store information and observe phenomena. The result of this study is a scientific statement that can mean a collection of scientific truths or a historically-created system of knowledge, and even a set of ideal arguments.

Assuming the interdisciplinary character of the research, as well as cognitive and utilitarian purpose, object and subject of study (in which the state of development of the theory and pragmatic action can be distinguished) can be specified (Sztumski, 2005, p. 20). The motivator to undertake these studies was the realization of problems arising from the interculturalism in crisis response operations.

The subject of the crisis response to the environment and the object, i.e. its characteristics, the environment and participants in multinational forces, are issues arising from the research subject, analysis of the study and the problem situation (Kamiński, 1998, p. 17-20).

In order to achieve the purpose of the study following main research, the problem was raised: To what extent interculturalism determines achievement for emergency response operations? The research required to develop partial problems for methodological testing:

1. What are the objectives of modern emergency response operations?

2. In which cultural environments did crisis operations take place at the turn of the $20^{\text {th }}$ and $21^{\text {st }}$ centuries?

3. How does the cultural environment affect accomplishments of the operation?

4. How to prepare participants of the operation to achieve established intercultural goals?

Responses to the selected problems have allowed finding the main solution to the problem and to achieve research objective. They result in a research material which synthesis constitutes the content of the article. 


\section{HYPOTHESES AND RESEARCH PROCEDURE}

By creating research hypotheses for inter-cultural considerations in crisis response operations, one of the basic conditions was a clear reference to this consideration, which could provide answers to questions arising from problems. In addition, it was important to have reasoned hypotheses, because this was a reference to the theoretical or empirical knowledge of the problem. It was also reasonable to evaluate conditions of verifiability of hypotheses.

During the research process, the main hypothesis (in alogical sense) was adopted: it was that interculturality is one of the main determinants of achieving the goal of crisis response operations because of its cultural environment, its social attitudes, its value system, intercultural communication, religion, language, traditions and customs.

The general hypothesis is expressed by several detailed hypotheses. The detailed hypotheses stem from detailed research problems related to the assumptions of contemporary crisis response operations.

The basic premise of a crisis response operation is to remove the causes and effects of a crisis and bring about a systemic change in its social environment to a level that does not allow for a recurrence of the crisis under previous circumstances. The purpose of crisis response operations is not to deprive the local population of subjectivity, but to create its conditions for safe development. The effects of crisis response operations do not impose on the local population a specific lifestyle, language, culture, or moral principles. During the operation, inter-cultural communication occurs that results in one of the conditions for achieving its goals.

The environment of modern crisis response operations is multidimensional and multifaceted. Crisis response operations from the turn of the $20^{\text {th }}$ and $21^{\text {st }}$ centuries were carried out on the border of European-Asian civilization and in a homogeneous Arab civilization. Civilization frontiers have a positive influence on inter-cultural communication because of their previous contacts, while a homogeneous environment hampers communication due to their lack of communication. Communication with people from different civilizations is at risk of misunderstanding or error in understanding interactions. The environment of crisis response operations affects interactions between different cultures. This requires participants to learn about the culture, religion, language, and customs of the area. The determined civilizational environment of the operation requires its participants to reject ethnocentric attitudes towards inter-cultural communication. 
The multicultural environment of crisis response operations is an important process of information exchange - an act of communication and understanding between representatives of different cultures, influencing the achievement of the purpose of crisis response operations. Adequate preparation of participants to achieve its goal should take into account civilizational and cultural aspects in order to achieve the expected level of intercultural communication. The civilization and cultural environment of the operation, in a view of its location, will manifest its cohesion as an instrument for defending its identity, therefore it is necessary to convince the local people of the intentions and objectives of the operation to gain them to build their future.

In conclusion, it is reasonable to put a probationaryhypothesis that interculturality significantly influences the achievement of the purpose of crisis response operations in a diverse cultural environment. Hence, participants in crisis response operations should be properly prepared in terms of knowledge of similarities and cultural differences to have the capacity to establish inter-cultural communication. The result of inter-cultural preparation should be the ability to communicate, tolerate, and understand other civilizations in terms of their expectations, aspirations, and values.

In order to achieve objective results, a specific test procedure was used. The process of conducting the study has been divided into stages, which constitute the scientific method. In the conducted research, the procedure was organized and carried out according to phases and stages of scientific work. In general, this research paper has adopted the overall research procedure (Table 1):

1. the stage of preliminary research,

2. the stage of applied research,

3. the stage of finalization of the research.

The first stage of scientific research (theoretical stage) consisted of formulating a problematic situation and developing a research procedure. Then the research methods, techniques and tools were selected and the working hypotheses (main and detailed) were developed. The research was subjected to the process of conceptualization through which a precise conceptual apparatus was created. The exemplification method enabled access to study with hypotheses, and the research material was used as illustration and hypothesis verification.

In the next stage, theoretical and practical research was taken into consideration to allow achieving the final goal. Accounting the typology of social research, it should be emphasized that research was conducted within a Muslim society from the border of various civilizational circles. This undertaking involved 
research that ultimately established research methods which then allowed verifying the accepted objectives. The implementation of applied research was possible due to use of the monographic method, observation method and questionnaire. The utilized qualitative analysis, along with the classification of issues and dependencies, completed the statistical analysis, what enabled to point out all dependencies between elements of the studied system or environment.

As a result of the implemented methods, a comprehensive picture of the problem was obtained. Theoretical and empirical studies were organized and conducted. Moreover, the hypotheses were tested.

In the final stage of the study, the material was verified and the results were tested in a synthetic form. This procedure enabled the summary of the study as a whole, as well as the final editing of the doctoral dissertation.

Table 1. Course of the research procedure

\begin{tabular}{|c|c|c|}
\hline Stages & Actions & \\
\hline \multirow{10}{*}{$\begin{array}{l}\text { Stage I } \\
\text { Preliminary } \\
\text { research }\end{array}$} & step 1. & formulating a problematic situation \\
\hline & step 2. & preliminary defining and identifying the research problem \\
\hline & step 3. & collecting of source materials \\
\hline & step 4. & developing a research procedure \\
\hline & step 5. & selection of research methods, techniques and tools \\
\hline & step 6. & formulation of working hypotheses: main and detailed \\
\hline & step 7. & conceptualization of research \\
\hline & step 8. & creation of a precise conceptual apparatus \\
\hline & step 9. & exemplification, which led to the study with some hypotheses \\
\hline & step 10. & verification of pre-applied methods, techniques and research tools \\
\hline \multirow{8}{*}{$\begin{array}{l}\text { Stage II } \\
\text { Applied } \\
\text { Research }\end{array}$} & step 11. & selection of research sample \\
\hline & step 12. & preparation of research tools - questionnaire survey and interview \\
\hline & step 13. & application of qualitative and quantitative analysis \\
\hline & step 14. & classification of issues \\
\hline & step 15. & formulation of dependencies \\
\hline & step 16. & $\begin{array}{l}\text { organizing and implementing theoretical and empirical } \\
\text { research }\end{array}$ \\
\hline & step 17. & $\begin{array}{l}\text { statistical analysis of data collected from survey questionnaires and } \\
\text { interviews }\end{array}$ \\
\hline & step 18. & $\begin{array}{l}\text { pointing all dependencies between elements of the studied system or } \\
\text { environment }\end{array}$ \\
\hline
\end{tabular}




\begin{tabular}{|l|l|l|}
\hline Stages & \multicolumn{2}{|l|}{ Actions } \\
\hline \multirow{4}{*}{$\begin{array}{l}\text { Stage III } \\
\text { Finalization } \\
\text { of research }\end{array}$} & step 19. & preparation of empirical data for statistical analysis and calculation \\
\cline { 2 - 4 } & step 20. & qualitative and quantitative analysis \\
\cline { 2 - 4 } & step 21. & preliminary verification of hypotheses \\
\cline { 2 - 3 } & step 23. & $\begin{array}{l}\text { interpretation of the results of theoretical research, survey research and focus } \\
\text { group interview, in the context of research problems }\end{array}$ \\
\cline { 2 - 3 } & step 24. & verification of hypotheses \\
\cline { 2 - 4 } & step 25. & $\begin{array}{l}\text { development of assumptions and guidelines for planning the training } \\
\text { in the field of cross-cultural interventions in crisis response operations }\end{array}$ \\
\cline { 2 - 4 } & step 26. & $\begin{array}{l}\text { preparation of final conclusions and results of research in the form of } \\
\text { a doctoral dissertation }\end{array}$ \\
\hline
\end{tabular}

Source: Own elaboration.

The use of the given methods is justified due to the interdisciplinary character of the conducted research. Into research, methods tools and research techniques were applied accordingly to the process of the research and its objectives.

Due to the interdisciplinary character of the research in the field of social sciences, the essence and nature of this science should be emphasized in the context of its dissertation. Inter-cultural issues in crisis response operations are closely linked to the field of social sciences, the discipline of defence science, security, politics and sociology. In addition, the research area refers to the humanities in cultural and anthropological fields.

The probability of the reliability of the test results was based on statistical inference. Within the statistical inference, one of the two potential coefficients was distinguished. It is verification that tests statistical hypotheses by checking certain assumptions about the type of theoretical distribution, parameters of this distribution and the interdependence of features.

The probability of the test results was verified by means of the verification index and through the severity test group. They are constructed to make it as unlikely as possible to commit a second kind of error with a predetermined and accepted probability of making the first kind of error. This probability $a$ is defined as the level of significance. Significantly small positive numbers were considered as significant:

- $a=0.1$ (level of high significance),

- $\alpha=0.05$ (level of medium significance),

- $a=0.01$ (level of low significance). 
In fact, only one of the two possible choices is tested. Rejected hypothesis or stated at this level of significance for the results obtained in the sample have no grounds for rejection.

During field research, 423 people were tested in different cultural areas. After the verification, 123 questionnaires were rejected. The basis for the rejection of the questionnaire was the impossibility to read the data. As a result of the research and verification, 300 questionnaires were filled-in correctly. During the focus group interview, 48 respondents were surveyed. Based on the received responses, 8 of them were rejected as not meeting the criterion for further study.

The survey imposed an age restriction on respondents - minimum 18 years old with writing and reading skills.

The population surveyed during the focus group interview was not chosen due to the position or military rank but to the length of staying in the Republic of Iraq and the Islamic Republic of Afghanistan. The research was based on the experience of Polish officers serving in Afghanistan and among other participants, a component of multinational forces from Canada, Germany and France.

Although the gender criterion was not a major determinant of the selection of population, gender-based discrepancies in the survey and focus study were demonstrated.

During field research, $59 \%$ of the respondents were male and $41 \%$ were female. This almost equal division is insignificant with regard to the research problem among Muslim women, to which research results will show the general problem of the study. For comparison, during the focus study, only three women participated in the study of crisis response operations. It should be underlined that gender does not play a significant role in the importance of research issues.

Intentionally, the selection of the population was associated with the choice of conducting research in the Middle East and North Africa. This was due to the need to demonstrate the effect and impact of religious aspects on all spheres of life in the area of operation.

The age of the respondents can be determined in the range from 25 to over 45 years. The largest group of respondents were between 25 and 35 years old 227 people. Subsequently, 36 respondents were between 18 and 25 years old. In addition, 20 respondents were between 35 and 45 years. The smallest group of respondents are those over 45 years of age.

Intercultural research in crisis response operations has been carried out in several parts of the world. The main motivating factor for research in different regions was the cultural, social and religious criterion and multinational forces 
in this area. The focus was primarily on the potential for research in single and multicultural areas. The result of this assumption was to conduct research in countries with different ethnic, religious and geographical structures.

\section{MODERN CRISIS RESPONSE OPERATIONS - RESEARCH FINDINGS}

Socio-cultural understanding is a result of a series of actions that over time lead to the building of intercultural awareness: starting with respect, building a fundamental relationship between multinational forces and local society, trust and creating a team that will have all the features of multiculturalism.

To illustrate these considerations, the structure of the factor scale was used. The data used in the study come from an interview questionnaire conducted among participants in the mission and operations in Afghanistan.

The random sample consisted of 40 members of coalition forces. Only those who spent a minimum of three months in Afghanistan were included in the analysis.

Analyses assessed the essence of cultural awareness during operations against other needs related to the level of knowledge of participants in the operation, according to V. Schrab (Schrab, 1943, p. 16-25). Selected needs have been based on obligatory courses performed during the preparatory training of soldiers qualified for the Polish Military Contingent.

Respondents' assessment of the need for understanding cultural differences, in comparison to other competencies, were identified by the variables of responses to the questions in the questionnaire (Appendix I). Is cross-cultural understanding - cultural awareness - less important, as important as, or more important than:

- $V 1$ - Military discipline,

- $V 2$ - Psychology,

- V3 - Situation of civilian environment,

- V4 - International Humanitarian Law of Armed Conflicts,

- $V 5$ - Legal training,

- V6 - Improvised Explosive Device countermeasures.

Respondents assessed the importance of understanding the cultural difference with respect to others (Table 2) using the Stapel's scale, from -5 to +5 , where these values were: 
- -5 was definitely less important,

- 0 - equally important,

- +5 - definitely important.

Furthermore, 2\% of respondents chose "hard to say" category for at least one pair of needs without revealing their preferences, but they did not refuse to answer. On the one hand, the omission of missing answers in the analyses distort their results and, on the other hand, as G. King, J. Honaker, A. Josephi, and K. Scheve has rightly pointed out, it does not make sense to imply values that do not exist (G King, J Honaker, A Joseph, K Scheve, 2001, p. 49-69).

Imputation is justified only when the respondent has an attitude but does not disclose it. In practice, it is difficult to determine unequivocally whether a respondent actually has no opinion on a given topic or just does not want to disclose it, masking this fact by saying "hard to say". Therefore, the answers hard to say were not assigned to the rating scale.

Structural equation modelling, i.e., the factorial analysis, was used to construct a factorial scale to measure the substance of cultural awareness during operations in Afghanistan and evaluate its validity.

Calculations were made (Table 2, 3) in SPSS (Amos). Variables, used as indicators in the measurement model of the essence of intercultural awareness, were measured on the order scale. In this situation, one can treat the scale as a compartmental.

The results of a statistical analysis based on factorial scale indicate the validity of the thesis that participants in operations in the Islamic Republic of Afghanistan positively identify the importance of knowledge in terms of cultural diversity. Researchers pointed out that military discipline is fundamental, but this material is not new and the time spent on improving it is more important to spend on something more important. Certainly, more important than the problem of cultural diversity is training against counterfeit explosive charges. Respondents had trouble deciding on variable V3, namely, the situation of the civilian environment. This is due to the fact that the subject should be included in interculturality, as well as the cultural studies that are present in the training before going on a mission. Variables V4 and V5, these are the International Humanitarian Law of Armed Conflicts and Legal Training - Rule of Engagement, were defined at a similar level of significance as intercultural awareness. 

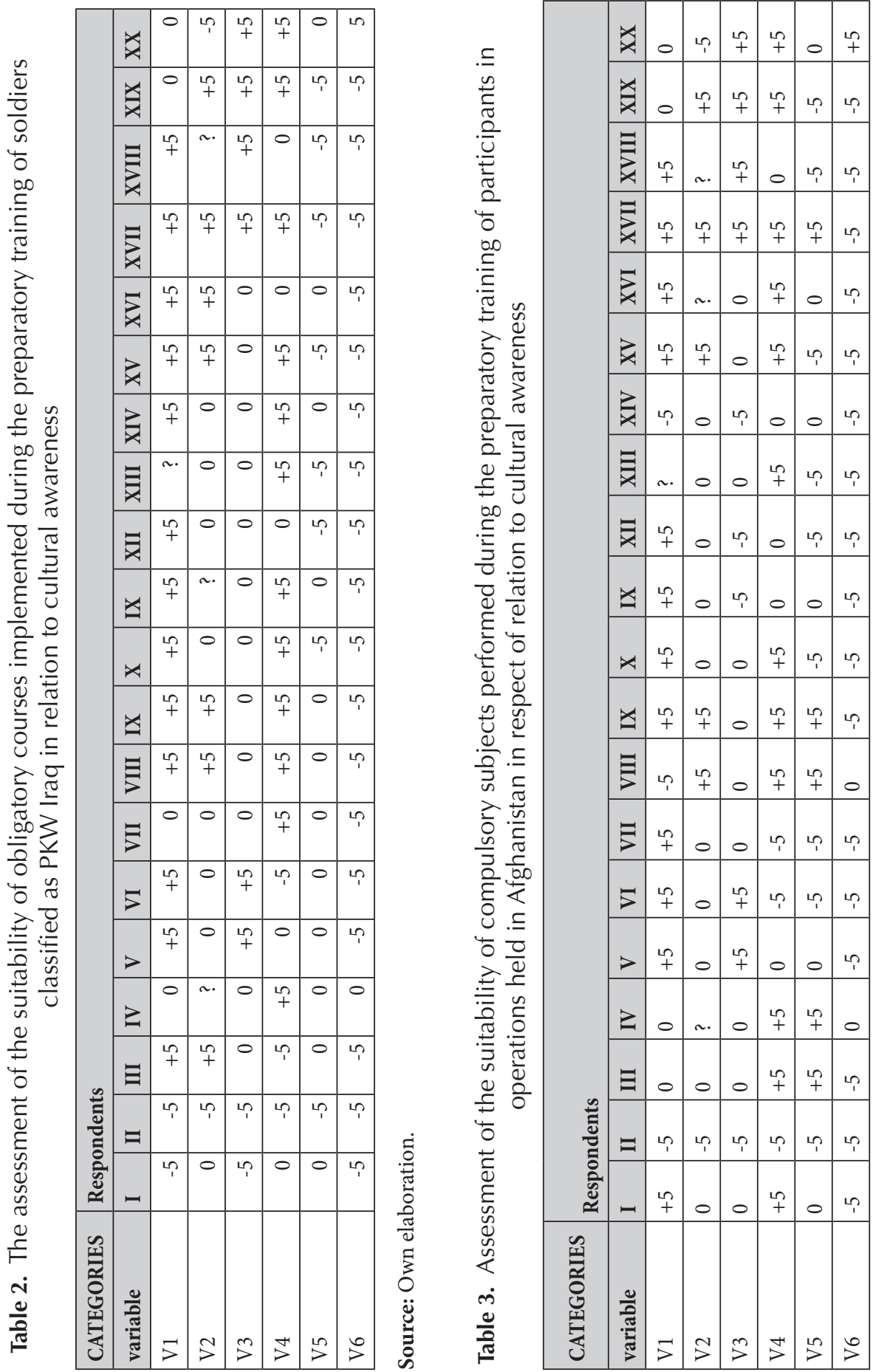

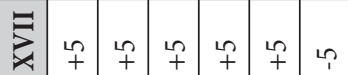

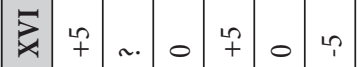

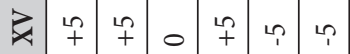

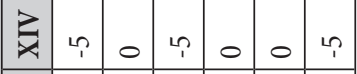

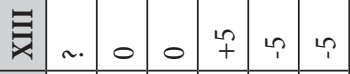

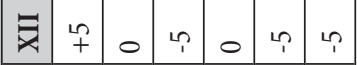

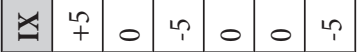

\begin{tabular}{lllllll}
$x$ & in & & & & in & in \\
\hline
\end{tabular}

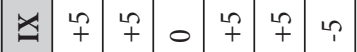

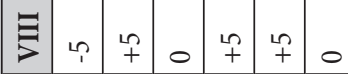

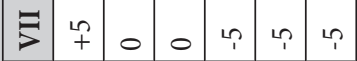

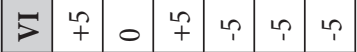

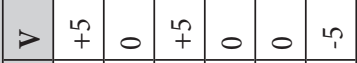

\begin{tabular}{lllllll}
$Z$ & 0 & $\sim$ & 0 & $\ln$ & $\operatorname{Ln}$ & 0 \\
\hline
\end{tabular}

$\begin{array}{lllllll}\omega & \frac{2}{d} \\ 0 & 0\end{array}$

苛

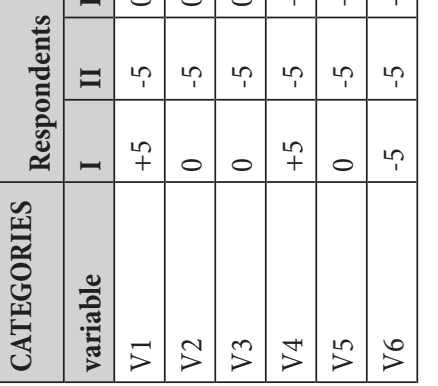

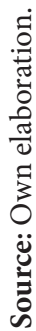


It appears, therefore, that the results of this study, in connection with intercultural awareness and understanding of cultural differences, give grounds to assert that they have a multidimensional and interdisciplinary character. In addition, it can also be suggested that this substitution is a hidden variable. This creates a conceptual measurement model based on assuming the existence of a hidden variable. In addition, there are several hidden variables, so there is a chance to explain the correlation observable variables.

As a result of the analysis and cultural experience of participants in multinational forces, it is necessary to conclude that intercultural awareness is shaped throughout life, in principle influenced by experience and situations, where there was a chance of contact with the local population in Afghanistan.

Participation in crisis response operations under the aegis of NATO and the significant role of the United States in the presented examples is a testament to the determinants of international environmental impact in certain parts of the world. The dynamically changing environment creates new challenges for international security. It can be argued that the actions of coalition members are based on the view that instability in different parts of the world, especially where terrorist organizations, extremist movements, fundamentalists can spread to other areas, thereby affecting the level of national and international security. It is then reasonable to argue that there is a need for intervention in these regions of the world and help the international community. First of all with a focus on the highly developed the European Union Member States and the North Atlantic Alliance, organizations that support pro-state mechanisms and democratic processes in crisis regions. This obliges all intervening parties to make the necessary adaptation effort within the state to meet these challenges. It also highlights the need for economic, social and military engagement in addressing global security issues. Hence the participation of participants in the international coalition in Iraq and Afghanistan.

\section{MULTICULTURALISM FOR PEOPLE AND THE ROLE OF INTERCULTURALISM - RESEARCH FINDINGS}

In Western culture, it is very popular to use words like 'all', 'every', 'always', 'everywhere', 'often', or 'usually'. People often assume that their beliefs and their understanding of phenomena are the most sensible, true, important, universal for everyone and everywhere. This also applies to culture and art. Perception 
changes when people leave the country or civilization. It suddenly turns out that their values and behaviours are inappropriate or even incomprehensible to the local population. The multiplicity of cultures meant that they were still in the process of developing and systematizing so-called cultural variables. In this context, the most important are the relations between the different cultures that realize international transactions. Therefore, we can distinguish eight different types of cultures, due to trade or negotiation, namely cultural, transactional, solemn and hierarchical, not solemn, egalitarian, polychromatic, reserved and expressive (Michałowska, 1997, p. 42-43).

In turn, the types of cultures could be replaced by the continent in which they are located, or the culture: European, Asian, Arab, African, American, South African.

It is also possible to distinguish the typology of religious cultures. Religion is a system of beliefs and practices adopted in society, and therefore elements that form the notion of "culture". This is a very important aspect in the context of research into interculturalism. It can be distinguished by the culture of Christian Orthodox, Muslims, Buddhists, Judaic, Chinese, Protestants (Lizak, 1997, p. 71-73).

It is thus possible to distinguish the types of cultures that occur in each country due to the relationship. On this basis, it is possible to identify the symbolic, social, national, folk, mass media, niche and any other counterculture. There are three zones of categories of the cultural diversity of interdependence: ideology, political practice and description of social reality. Ideology is primarily a doctrine, an idea, a philosophy and a basic social activity. For example, it is a curriculum that teaches the content of schools at the lowest level of education. Children on every continent have been shocked by the rules of the cultural circle. They live and grow up according to the philosophy of life, which has the right to be different in other cultures and societies. The political practice involves the implementation of the principles of social ideology. Its subject groups and people with cultural characteristics differ from the dominant culture. The last sphere, the description of social reality, is an objective fact of the coexistence of different cultures in society and the related consequences and problems.

Very strong tendencies are increasing interest in national and international organizations with national and cultural problems. They affect the direction and intensity of interaction in the international community - equally at the global, regional and national level. Defining functioning of international entities is particularly the process of defining their interests and decision-making. 
A sign of the growing importance of cultural issues is the increasing number of ethnic-religious and social conflicts. Society feels rising threats by the influx of migrants, the flood of foreign cultural patterns, loss of national identity and respect for tradition. In the meantime, the possibility for States to provide safety culture for its citizens is decreasing. This fact is increasingly becoming a source of danger for the cultural identity of ethnic and religious groups (Golka, 1997, p. 54).

The growing importance of the cultural factor does not, however, mean the loss of importance of the traditional dimension of security. It should be noted that all its components are related and the artificial isolation of one element is justified for analytical and purely scientific purposes. This in particular concerns the relationship between political, cultural and military security. Safety culture is political, because of the risks and the definition of the protected entities as a political act. In addition, specific security phenomena of the dimension of cultural legitimacy give a specific government policy. Despite the increased political importance of non-state actors, it should be borne in mind that they are still important actors on the international scene.

\section{INTERCULTURALISM IN THE MILITARY OPERATIONS ENVIRONMENT - RESEARCH FINDINGS}

Providing security is certainly a viable way to improve intercultural communication. Otherwise, people behave in a situation of guaranteed peace and security as the basic existential necessity of man as in eternal crisis and state of instability, like in Afghanistan or Iraq. It is important to have an empathy, mutual understanding and compassion, and above all, to have respect for cultural and religious diversity. These elements are intercultural. It is important to be able to feel the needs of the other person and understand her or his way of thinking along with her or his life situation. Without it, no matter what the reasons, it will be a fight where two sides will lose. Therefore, one should:

- learn about another culture, religion and customs,

- try to understand it,

- demonstrate understanding and patience in getting to know each other.

In this connection, what role the multicultural context of participants in crisis response operations should have to play? A multicultural and intercultural context fulfils not only a cognitive role but can also initiate an element of 
dialogue in mutual contacts. In addition, it makes it easier to arrange contacts with local communities through the knowledge of their culture, religion or social relationships. Much greater acceptance in intercultural relationships bring people who do not try to impose their own way of thinking or behaviour. In Muslim communities, it will be hard to find the conviction that something new will mean better and more useful. The Muslim ummah is quite homogeneous and has traditional societies, which rather suspiciously refer to people coming from abroad. That is why it is all more important for the Armed Forces to be stationed in a specific area.

There are prejudices that manifest themselves in a general unwillingness to other different groups. Found on both sides - a strange dress and behaviour. The attitude of the local population with an additional military contingent come to the forefront of nationalism: let them go back where they came from, we do not want them here, they speak a different language, which we do not understand, we can fool them, etc. Typical allegations against the different communities which are accused of receiving the work, the use of the social system, the dominance of foreign customs of the natives.

A multicultural context is the unification of society through the ability to know and understand local people and their culture. In this regard, these are knowledge, learning, support, activation of the local population, positive relationships, knowledge of cultures, confidence and knowledge transfer.

In conclusion, it should be emphasized that interculturality is a network of interaction that aims to improve and influence the relationship between participants in crisis response operations and the civilian population and between participants in the operation.

\section{PREPARING THE POLISH MILITARY QUOTA IN TERMS OF INTERCULTURAL COMMUNICATION - RESEARCH FINDINGS}

The conclusions of the study conditions of the cultural achievement of the operation indicate that their nature requires extensive cultural knowledge. Religion and culture are a powerful force, which simultaneously connects and divides society. Lack of skills of agreement among societies causes the phenomenon of troublemaking.

The study shows the low socio-cultural awareness and lack of knowledge in the area of operations. There have also been no published materials that will 
move the whole intercultural issue into crisis response operations. Only a few are available, but generally, there is no proposal for a direct security culture in a given area. Participants of the Armed Forces did not have the possibility of finding didactic material created specifically for their needs. An interesting material would also cover the experience of CIMIC undertaken activities. An increase of knowledge about interculturality should be put at the very beginning of education (Elak, 2010, p. 45).

There are not too extensive databases and applications on the activities of the Armed Forces actions in a multicultural environment. This is closely related to SI participants in the Multinational Forces taking part in the conflict. It turns out that cultural training does not meet needs or is too extensive. On this basis, there appeared a need for a comprehensive cross-cultural and intercultural communication training for crisis response operations.

Education in the field of multicultural communication and interculturalism should be carried out continuously throughout the period of training of the Armed Forces. Therefore, it is reasonable to undertake educational activities such as:

- introduce the subject of intercultural education in the Armed Forces, which is a separate part of socio-cultural or civilizational security implemented in academies and colleges for officers,

- intensify the cultural training for future participants in emergency response operations,

- expand knowledge of intercultural postgraduate studies.

The subject including teaching intercultural issues should be conducted on the first stage of education of future officers, and as an introduction to the further exploration of the issue providing on military academies, also for the composition of the educational and training curriculum should cover the following social issues:

- culture,

- cultural identity,

- education in multiculturalism,

- importance of religion in the culture,

- civilizations of the world,

- faces of multiculturalism,

- collision and socio-cultural dialogue,

- interculturalism (intercultural nature, intercultural determinants),

- opportunities, threats and challenges of interculturalism. 
Continuing studies on the second degree for officers should be the safety of the socio-cultural, moving subjects crisis response operations and space factor of socio-cultural. Conclusions from the analysis of the knowledge of the cultural awareness factors can be presented through the mandatory topics that will broaden knowledge of the issues:

- international safety (place of safety socio-cultural),

- nowadays crisis response operations,

- operational aspects of emergency response operations (NATO, the EU, the UN),

- the militarization of culture,

- cultural strategy,

- Iraq (interculturalism Iraq, actions, cultural experiences of soldiers PKW Iraq),

- Afghanistan (interculturalism Afghanistan, the role of interculturalism in the ISAF operation, cultural experiences PKW Afghanistan),

- Balkans (cultural identification in the Balkans),

- multicultural international environment,

- intercultural communication,

- negotiation.

Another aspect of the training can be active cultural training for future participants in crisis response operations (Roman, Bassarab, 2008, p. 3-5). Without focusing on these issues during the training of the Armed Forces there will be no positive reinforcement. The culture of the region comprises only one of several aspects of the training of soldiers. Moreover, it is essential that the aim of this training is to deepen knowledge and understanding of useful principles of intercultural communication, not the creation of experts in the field. It is hard to understand the mentality of another community and its values and principles in just several hours. However, it is important to be aware of them and to try to understand them. The real challenge is to use acquired rules in the area of operations, to not break them.

Training of Polish military contingents in a cultural context requires a detailed analysis of the area and cultural conditions in the region. The teaching process must be adapted to the continuous changes in social conditions in the field of activities. Training programs should be constantly updated and tailored to the needs of the participants in the operation. It is important to respond to training for future functions and tasks that will have to fulfil the additional learning needs. 
The basis of the training system of cultural or intercultural competence should be held through cultural analysis, which will include answers to the following questions:

1. What are the similarities between us (PMC) and the local people?

2. What makes us different and can it cause conflicts?

3. What elements of everyday life are not seen, namely, what area of life will be available for us?

The next step is to prepare an extensive SWOT analysis on the basis of which all these elements will be developed:

- asset, advantage, analyzed the advantage of society and the environment,

- weaknesses, considering a weakness as a barrier analyzed in society and the environment,

- chance of positive change,

- threats, an example of everything that would cause a change at the expense of society and the environment.

A tool that allows an increase of the accuracy and effectiveness of planned activities is the method of PEST, differently called as a general segmentation of the environment. On the basis of the environment, it is divided into:

- political and legal,

- economic,

- social,

- technology.

This method is used to study the macro-environment, and in this aspect a different cultural environment conducts emergency response operations. The essence of this tool is to identify the key areas of the environment, meaning those areas that may have a crucial impact on the functioning of society and its further actions.

On the basis of the gathered information, it is possible to collect basic sociocultural information. This will be done by revisiting the approach of the local population to name, identity, ethnicity, language, territory, and the approach to weapons, violence, culture, traditional beliefs, legends, symbols, and taboos (Roman, Bassarab, 2008, p. 3-5).

The essence of cultural analysis, in order to achieve the effectiveness of the activities conducted by emergency response operations, will also be getting answers to the following questions:

- What makes the group creating a structure, the mutual network connections? 
- How to describe social groups, their history, and determine whether its origin?

- How organized are groups of different social relations (class, ethnicity, tribalism)?

- What are the motivations of the ruling groups?

- Who has the most popular support?

To sum up, it should be highlighted that the participants of multinational contingents should be properly prepared in terms of cultural similarities and differences, to have the ability to establish communication. The effect of the intercultural preparation should be the ability to establish communication, tolerance and understanding of other civilizations in terms of their expectations, aspirations and values.

\section{CONCLUSIONS}

To conclude from each part of this dissertation it was required to identify challenges and prospects of interculturalism in crisis response operations. Based on the survey, it was specified that the challenge for coalition forces will be primarily the implementation of interculturalism and intercultural awareness in the process of military planning. In this context, the important knowledge to gain would consider:

- culture and values of the society in the area of operations,

- perception and communication of the society to the intervention forces,

- emotional needs of the local population.

The challenge facing interculturality is cultural relativism, which in the contemporary world becomes increasingly difficult to manage. A proposition that assumes that every culture has some value is self-evident. Still, culture in crisis response becomes a challenge in the context of different civilizations and their cultures.

The another challenge of interculturality is to build one common, cohesive, multicultural society. The media, which inoculate the social attitudes and values in people living in different corners of the world, play an important role here. The media form human view and values of the world, namely what we consider good or bad, positive, negative, or moral. It turns out media can as well hinder influence on the vision of creating an intercultural society. 
The challenge of interculturality is presenting cross-cultural information in an attractive way to the media in writing and speech and that it would be marked by negative narration.

The challenge for the Polish army is to properly present itself on the international forum. This is the key to strengthening Polish position as one of the guarantors of the modern international security system. It is also important to include socio-cultural aspects in the training programs. Thus, the flexible adaptation of the training program to the dynamically changing tactics of the opponent so that the soldiers are as versatile as possible in what they may encounter in the area of operations. It is fundamental to replace the overloaded theoretical material by other that can be applied in the activities (Collett, 2012, p. 4).

However, this does not change the fact that the closest perspective for interculturality can have a two-fold scenario. On the one hand, in a military context, the development of intercultural issues should be developed through effective and substantive training and courses, and, on the other hand, it may provoke hostility. It turns out that people are no longer so optimistic about interculturality and the idea of multiculti. The rise of nationalist movements in Belgium, the Netherlands, Germany, Austria, and Poland is noticeable. The negative phenomenon is also hostility of economic migrants, seeking better living or social wellbeing in some European countries (mainly in Great Britain, Germany, France and the Scandinavian countries), towards citizens of different civilizations.

In a military context, it should be anticipated that the improving of preparation of contingents for crisis response operations will be made. What is more, the skill and experience of the soldiers should occur in combination with speed and efficiency. International experience shows that the military is also largely based on a non-military system that supports action in a variety of situations. That is the reason why, over time, the value of people with specialist knowledge of areas affected by crisis response will increase.

Taking into account the need to verify the hypothesis, a monographic method of analysis and criticism of literature research was used as the research method a diagnostic method that was sufficient to achieve the research objective.

It is worth to emphasize that in the long-term perspective, intercultural research must consider other aspects of interculturality, such as the methodology of training in this field or the negotiation of culturally diverse environments.

The conclusions of the study confirmed the hypothesis that interculturalism is one of the main determinants of achieving the objectives of emergency 
response operations, due to the cultural environment in which it is conducted, social attitudes, value system, intercultural communication, religion, language, traditions and customs.

The chance of the armed forces to successfully achieve the goal of the operation is to integrate the activities of specialists and intercultural experts beginning in the field of land recognition and the preparation of operations. Therefore, knowledge of interculturality is a resource enabling the greatest possible civilmilitary cooperation to avoid conflict or its spread.

Apparent of the fact that interculturalism is not only feasible, results in an immediate dialogue and compromise. Soldiers-anthropologists cannot solve all the problems, but their presence reduces the number of military operations by up to $60 \%$, accordingly to the American experience. Equally important, for the participants of abroad operations, are language skills, and the particular role played by interpreters of foreign languages, including Arabic, Farsi, Dari, and Pashtu. In addition, the essence of anthropologists and translators in the area of operations is increasingly emphasized by the fact that the negotiations can often be ineffective without them.

While making conclusions about generalizations related to interculturality in response to the crisis, it should be highlighted that it is a dualistic way of checking reality. Soldier - social and cultural participant of the operation, by studying the reality will use interculturalism for military purposes (going beyond the scientific vision of the basic theory of intercultural anthropology). Interculturality is a practical field of learning and can be fully tested in empirical field research that was presented in this thesis. The implementation of intercultural knowledge can bring many positive events in the activities of participants in the operation. The empirical character of the foregoing image of the intercultural community allows for better relations with the local population, faster access to compromise, rebuilding the destroyed country, and improving the lives of the people in the data area.

The essence of intercultural problems due to the necessity of the participation of international forces in forming global security and the experience of Afghanistan and Iraq should be the basis for reformation of soldiers' training before participation in multinational operations.

Conclusions from the analysis also show that knowledge of the cultural area of conflictmaybeuseful to effectivelyand efficientlyachievethepurpose of theoperation. The legitimacy of further research in this field also highlights the fact that the area is closely related to the social sciences, which are a part of the security and 
defence. This is confirmed by the purpose of the social sciences, which is to identify the areas of social sciences and scientific disciplines, including their political, security, defence, communication or sociological aspects. In addition, used methods, techniques and tools indicate the ability to use components of social research, which include observations (observation of fact), facts, laws.

It also agrees with the form of accepted studies, according to which the traditional - classic image of the issues is being passed from theory to observation, through the phenomenon of operationalization in the conducted research methods, which are interpenetrating and complementing each other. Whereas the author of the work tried to generalize the conclusions to prioritize the objectivity, openness and logic.

\section{APPENDIX I}

\section{QUESTIONNAIRE}

Cross-cultural awareness

1. How do you understand "culture"?

2. What belongs to Arabian culture?

3. What do you think is good in Arabian culture?

4. What is wrong or bad in Arabian culture?

5. Are you interested in another culture?

\begin{tabular}{|l|}
\hline - Yes \\
\hline - No \\
\hline - I have no opinion \\
\hline
\end{tabular}

6. Is something as interesting in an Arabian culture that you want it to cross over to your country?

7. What should be changed in Arabian culture and why?

8. Which Arabian tradition is interesting for you? 
9. Are Libyan people interested in another culture?

\begin{tabular}{|l|}
\hline - High \\
\hline - Medium \\
\hline - Low \\
\hline - No respect for other cultures \\
\hline
\end{tabular}

10. Do Libyans read not-Arabic press?

\begin{tabular}{|l|}
\hline - Yes \\
\hline - No \\
\hline - I have no opinion \\
\hline
\end{tabular}

11. What is the "multiculturalism" and how do you understand it?

12. Do you think the dialogue between cultures is possible and real?

\begin{tabular}{|l|}
\hline - Yes \\
\hline - No \\
\hline - I have no opinion \\
\hline
\end{tabular}

13. What do Libyans think about people from another culture? - Yes

- No

- I have no opinion

14. Do you think that multiculturalism is possible in Libya?

\begin{tabular}{|l|}
\hline - Yes \\
\hline - No \\
\hline - I have no opinion \\
\hline
\end{tabular}

Thank You for Your time 


\section{REFERENCES:}

Bagozzi, R., Yi, Y. (2012). Specification, Evaluation, and Interpretation of Structural Equation Models. Journal of the Academy of Marketing Science, 40(1), 8-34. DOI: 10.1007/s11747-011-0278-x.

Best, R., Cumming, A. (2007). CRS Report for Congress, Open Source Intelligence (OSINT): Issues for Congress. Congressional Research Service, Order Code RL 34270, 1-24. Retrieved from: https://fas.org/sgp/crs/intel/RL34270.pdf.

Burszta, J. (1998). Antropologia kultury: tematy, teorie, interpretacje. Poznań: Wydawnictwo Naukowe UAM.

Collett, E. (2012). The EU Immigration Pact - from Hague to Stockholm, via Paris. Retrieved from: Policy Brief, Publication of the European Policy Center, http:// www.epc.eu/documents/uploads/304970248_EU\%20Immigration\%20Pact.pdf.

Elak, L. (2010). Funkcjonowanie polskich kontyngentów wojskowych poza granicami kraju. Warszawa: Akademia Obrony Narodowej.

Golka, M. (1997). Oblicza wielokulturowości. In: M. Kempny, A. Kapciak, S. Łodziński (eds.), U progu wielokulturowości. Nowe oblicza społeczeństwa polskiego (p. 56-72). Warszawa: Oficyna Naukowa.

Granberg, G., Gilljam, M. (1993). Should We Take Don't Know for an Answer? Public Opinion Quarterly, 57(3), 348-357.

Grobler, A. (1993). Prawda i racjonalność naukowa. Kraków: Wydawnictwo Inter Esse. Jöreskog, K.G. (2012). Structural Equation Modeling with Ordinal Variables Using LISREL. Retrieved from: http://www.ssicentral.com/lisrel/techdocs/ordinal.pdf.

Kamiński, S. (1998). Nauka i metoda. Pojęcie nauki i klasyfikacja nauk. Lublin: Towarzystwo Naukowe KUL.

King G., Honaker J., Joseph A., Scheve K. (2001). Analyzing incomplete political science data: An alternative algorithm for multiple imputation. American Political Science Review, 95 (01), 49-69.

Kucharczyk, J. (1996). Kłopoty z wielokulturowością. In: A. Jawłowska (ed.), Różnica i różnorodność. O kulturze ponowoczesnej - szkice krytyczne (p. 51-73). Poznań: Wydawnictwo Fundacji Humaniora.

Lizak W. (1997). Wpływ czynnika etnicznego na bezpieczeństwo międzynarodowe. In: R. Zięba, D.B. Bobrow, E. Haliżak (eds.), Bezpieczeństwo narodowe i międzynarodowe u schyłku XX wieku (p. 23-31), Warszawa: Wydawnictwo Naukowe SCHOLAR.

Michałowska, G. (1997). Bezpieczeństwo kulturowe w warunkach globalizacji procesów społecznych. In: D.B. Bobrow, E. Haliżak, R. Zięba (eds.), Bezpieczeństwo narodowe i międzynarodowe u schyłku XX wieku (p. 131-143). Warszawa: Wydawnictwo Naukowe Scholar.

Roman, P., Bassarab, R. (2008). ABCA - The Simulation Interoperability Framework Mapping Interoperability Requirements to Coalition Outcomes. NATO.

Schrab V. (1943). Ten Copy Appeals, Printers Ink.

Sztumski, J. (2005). Wstęp do metod i technik badań społecznych. Katowice: Wydawnictwo Uniwersytetu Śląskiego. 